\author{
Alessandro Prato \\ Department of Social, Political and Cognitive Sciences (DISPOC) \\ University of Siena \\ prato@unisi.it
}

\title{
A Special Case of Philosophical Reflection about the Origin of language:
}

\section{Victor, the Wild Child of Aveyron}

\begin{abstract}
The paper focuses on the analysis of Jean Itard's writings documenting the program of linguistic re-education of Victor de l'Aveyron, a wild child found in France at the end of the eighteenth century. When discovered, the boy was seemingly twelve or thirteen years old and suffered from a severe form of deficiency in his intellectual and linguistic development, which made him utterly unable to speak and communicate with others. Itard's original method of re-education is examined here in relation to both the positive results he achieved from a cognitive point of view (but also the negative ones from the point of view of the ontogenetic birth of language) and the most significant outcomes reached by the eighteenth century philosophy of language through Locke's and Condillac's semiotic theories.
\end{abstract}

Keywords: arbitrariness; abstraction; natural signs; language of action; special education.

\section{Imaginary wild children}

The case of the wild child of Aveyron was documented with particular care and precision by Jean-Marc Gaspard Itard (1775-1838) in two 
Mémoires $^{1}$ that the French doctor wrote during the years in which he educated and took care of the boy; these two texts aroused great interest among scholars and are of a remarkable literary value. ${ }^{2}$ The scientific interests of Itard ranged from medicine to philosophy and pedagogy, and included a deep knowledge of the most important writers of the European Enlightenment, especially Etienne Bonnot De Condillac (1715-1780), whose Essai sur l'origine des connoissances humaines (1746) Itard appreciated greatly. Indeed, throughout the eighteenth century Condillac's masterpiece represented one of the fundamental cornerstones for the reflection about language and the descriptive study of mental powers, exclusively based on observation and experience. In this work Condillac aimed to reconstruct the history of human intelligence (and language), so as to illustrate the way in which the operations of the mind develop, starting from sensations and ideas. He recognized only one initial operation, sensation, which is the foundation of all other more complex operations, a privileged example being the faculty of reflection.

The French philosopher imagines that it is possible to strip man of all occasional ideas or sensations, in order to find the original state of his cognitive potential. The more or less ideal model for this knowledge, identified with man's primitive state, is already to be found in the Gedanken-Experiment of the mute statue, which Condillac described in the Traite des sensations (1754). This experiment proves that the statue in question has similar procedures to those of children, the deaf, and wild boys, where the latter are considered to provide real contemporary counterparts to the natural human, which is otherwise unknown to us.

In his Essai Condillac develops a phylogenetic theory of the evolution of both thought and language, building the story of their origins in which he imagines that two children were lost in the desert before they had learned the use of signs. Condillac assumes that, living together, the two children began to associate the exclamations typical of each emotion with perceptions of which those exclamations are natural signs. Condillac gives the name of "langage d'action" to this mode of expression: a language made up of inarticulate cries, physical movements and gestures, which constitutes a sort of primordial semiotic/communication system, a preverbal stage

1 Mémoire sur les premiers développements de Victor de l'Aveyron (1801), and Rapport sur les nouveaux développements de Victor de l'Aveyron (1807). They can now be read in Ginestre (2004: 324-360).

I'am referring in particular to the studies by Malson (1964), Mannoni (1965), Moravia (1970, 1972), Lane (1976), Shattuck (1980), Formigari (1981), Sacks (1991), Genovesi (2000), Annacontini (2002), Ludovico (2006: 75-90), and Manetti (2007, 2010). 
where ideas are expressed simultaneously, according to the natural order in which things are given names simultaneously with the perception of the subject. This kind of language, despite having the advantage of rapidity and immediacy, proves to be confused and imprecise in many ways.

Condillac also imagines that the need to understand and redress the confusion of ideas, gradually led the two children to articulate a language with a holistic aspect, expressing fewer things at once and replacing the simultaneous movements with a temporally ordered sequence. It is in this way that the language of action starts to lose its natural character and becomes an artificial language, in which the transition from the purely symptomatic expression to communicative intention, from intuitive to discourse thought is realized. The need to understand one another induces the two children to learn the analysis procedures gradually, and subsequently to break down gestures into syntagmatic gestural units or to cry out loud with increasingly articulate voices. Before coming to the use of arbitrary signs Condillac imagines that there was a time when human conversation was supported by speech composed of both words and actions, in which sounds were distinguished through tonal changes: an economical way to identify numerous differences by means of a limited number of semiotic features.

Condillac further describes how speakers and interpreters learn to analyze their thoughts over the course of this evolutionary process: the analysis ultimately consists in observing things in sequence and order. According to Condillac, to facilitate the analysis of words, the two children imagined new signs analogous to natural signs. For the French philosopher it is therefore only through the dimension of signs that man embarks on the path to intelligence; the latter comes to differentiate itself from sensitivity thanks to the use of artificial tools. The use of signs makes memory and imagination free from the perception of the object, autonomous from the contingency of sensitive experience, and easier to use, thereby allowing a full access to the superior faculty of reflection. The richer and more varied the human repertoire of arbitrary signs is, the greater the combinatorial ability of the mind.

Condillac's interest in signs rests on the same assumption as his empiricism: the activity of the mind can only take place if the latter has a material sensitive support, consisting of signs. Condillac classifies signs into three types:

- accidental signs, those entities which, in some particular circumstances, are connected to some of our ideas. Signs of this type can stimulate the imagination, because through their presence they awake the memory of an available perception in our mind. For example, if something has been 
linked to the feeling of fear, the same feeling will appear each time the subject has to do with it;

- natural signs, such as cries, which immediately express feelings such as joy, pain, hate, etc. These are the most important manifestation of the language of action. A cry of pain, however, is not a sign if it is a simple consequence of the feeling; only when, as a result of an experience, a connection between this feeling and the cry that naturally follows is established, does the cry become a sign. Even accidental signs, like natural ones, spark the imagination, but it is not possible to intentionally use them: humans come in contact with these signs independently of their will, and by chance;

- institutional signs, which are related to human ideas only, and are available to the speaking community, who can deliberately and freely use them. Among these signs, linguistics signs - that is words - hold a prominent position: they are general in scope and arbitrary, insofar as they relate to groups of particular ideas, which do not have a pattern in nature and do not even have the same configuration in different individuals. The meanings of words coincide with the nominal essences mentioned by John Locke (1632-1704) in his Essay on Human Understanding (1690), whose lesson always remained an unavoidable theoretical point of reference for Condillac. All the operations of the soul beyond perception and imagination originate and develop thanks to the use of these signs, which mark the distance that separates humans from animals and their respective forms of communication.

These ideas on language are consistent with Condillac's rejection of nativism: in his opinion when a human being is born, he/she has no preconceived ideas; however language is a natural faculty because the elements composing it and the organs responsible for it are born with humans. The faculty of language is therefore innate, although there are no preconceived ideas; it cannot be considered the result of any kind of learning, as it originates with the body and, in a sense, is embedded in the genetic code of the individual. For this reason, while the faculty of language is shared by all members of the human species, regardless of the geographical area and the historical moment in which they live, individual languages (such as Latin, English and so on) are learnt and forgotten; they are therefore historical-natural organisms. 


\section{Victor, the real wild child}

The linguistic philosophy and the sensationalism of Condillac strongly influenced the scientific programs promoted at the end of the eighteenth century by the Societé des observateurs de l'homme. ${ }^{3}$ Condillac's insights on language were the basic instruments available, when the case of the feral child of Aveyron emerged. Victor was a boy of about twelve years of age who was found in the woods, after having lived in isolation for many years; he was in an extremely wild condition, and was unable to speak. This was not the first case of a discovery of a young man who had lived in isolation for a long period: in his Systema Naturae (1735), Linnaeus (1707-1778) had already recorded all the cases of feral children known to him, including, in the same century, that of two boys found in the Pyrénées in 1719. Condillac himself had referred to the case of the child raised by bears and found in the forests of Lithuania in 1694. Even Jean-Jacques Rousseau (1712-1778) in his famous Discours sur l'inegalité parmi les homme (1755), had drawn attention to the discovery, in 1724, of the wild Peter of Hannover. However, the recent case of the sauvage de l'Aveyron aroused great interest among philosophers and naturalists who were members of the Society, because they thought that it could offer the opportunity to effectively test Condillac's principles of analysis about the development of mental and emotional processes. The Societé des observateurs de l'homme established a commission for the study of this particular case, which included Degérando (1772-1842), Jauffret (1770-1840), Pinel (1745-1826) and Sicard (17421822). At the same time a heated debate was sparked on the Décade Philosophique - the Idéologues's magazine - because the case of the wild boy in their view was an ideal opportunity to investigate the foundations of human nature and its main features, as well as to study the role of the society in the development of language, intelligence and morality. This interest in the wild boy also attests to the trend - which was already wellestablished in the late age of the Enlightenment - to pay particular attention to the childhood of man and his growth process, which was properly argued.

It soon became clear to the observers that the greatest obstacle to the integration of the boy into civil life was his inability to speak. As the ideologues believed that this was due to a hearing deficiency, they decided to commit Victor to the Institut pour les sourds et muets, founded by the famous abbot de l'Epée (1712-1789), and directed, at the time, by

3 On the research promoted by the Society and the importance it had for the culture of the Enlightenment, see Moravia (1968) and Chappey (2002). 
Roche Ambroise Sicard (1742-1822). De l'Epée had developed a method of expression designed to give deaf people the opportunity to integrate into society and overcome the deficiency that separated them from people with normal hearing. Following de l'Epée's ideas, Sicard had also developed a system of gestural communication for the deaf, which was strongly influenced by Condillac's semantics. It was based on the conviction that the specificity of human communication does not consist in the emission of sounds, associated with meaning, but in formulating conventional general correspondences between actions and states of affairs. Sicard's langage des signes was clearly related to the well known Lettre sur les sourds et muets à l'usage de ceux qui entendent et qui parlent (1751) by Denis Diderot (1713-1784). Sicard himself considered his sign language a kind of handbook, which resulted not in the translation of linguistic expressions (as was the case with de l'Epée's method), but in a new and independent semiotic system.

De l'Epée's method had aroused great interest among the cultured circles of his time, and Condillac had himself attended some lectures of the abbot, acknowledging the value of his teaching. Thanks to the activities of the Institute, a fundamental change in mentality had occurred in France, which had led to the emancipation of the deaf and their integration into society, which up until then had excluded and marginalized them. ${ }^{4}$ The case of Jean Massieu (1772-1846), therefore, became very popular: he was a deaf and dumb boy, who hadn't received education until the age of thirteen and was only able to communicate with a rudimentary system of signs invented by him and his brothers - an essentially "private" system of signs, with no grammar or elaborate syntax. In the Institute, Massieu learned the language of signs, according to the Sicard's method, and written French, thus becoming able, over time, to fully integrate into society. He became an educator of deaf people himself and entered into correspondence with the greatest writers and intellectuals of the time.

Jean-Marc Gaspard Itard worked for the Institute too and later became an important specialist in ear diseases; he was entrusted with the re-education of the boy, thanks to the fact that he showed great interest in his case. Itard was convinced that the boy was not mentally impaired, contrary to the opinion of Pinel, who had decreed that the boy was suffering from idiocy, due to a serious and incurable brain injury; this is why, he argued, the boy had been abandoned in the woods. Itard instead believed that the child was basically

4 Important studies on this topic are Sacks (1991), Pennisi (1992), Chiricò (2014) and Gazzeri (2015). 
healthy and that his severe form of dumbness and the backwardness of his mental development were not symptomatic of any disease, but only the result of the complete isolation he had experienced during the years that are crucial for language learning; this condition meant that his recovery was possible. Itard also realized that the child was not deaf at all: while he was indifferent to the sounds of language, he paid attention to other types of sounds - such as the noise produced by crushing a walnut or the fall of a pine cone - that were part of his everyday life experience. When exposed to linguistic sounds, the boy gradually became sensitive to them too and thanks to his special sensitivity to the sound of the letter /o/ - every time he heard the word "oh" he would immediately turn around - Itard decided to name him Victor. Itard thought that a child deprived of all exchange of communication would be affected by backwardness in his development of language skills and that he could make up for the lost time and begin communication processes as soon as he was put in touch with a community of speakers.

In his two fundamental Mémoires, Itard explains in detail the work program he carried out for Victor's linguistic re-education. Victor was not a child in the proper sense of the term, because he had the boy of a fully grown adult, but because of his lack of education, he not only had animal, rather than human habits, but also senses and physiological traits. For these reasons his re-education started from the elementary exercising of the senses, designed to help him learn to detect different sensible qualities, to recognize sounds, for instance, and to distinguish shapes and flavors. Following this new exercising of the boy's sensory faculties, and through the exposure to visual, motor and behavioural impulses, Itard sought to fill Victor's mind with ideas and knowledge. He gradually began to teach the boy how to use 'institutional' signs, in order to develop those traits of civilized mankind that the state of nature, in which the boy had lived until then, had prevented him from developing. This re-educational program drew upon Condillac's aforementioned experiment of a speechless statue. Despite the positive results that disproved Pinel's negative diagnosis, the experiment was not completely successful, because Victor never learned to speak, and was never able to fully master and freely use the signs of the institutional language. Victor was able to pronounce one articulate sound: the word milk (lait); however the child resorted to such expression only when he had the food before him, using the word only as an exclamation, that is a natural sign of his state of mind and not as a sign denoting that object. Itard himself, in fact, was aware of the lack of success of this experiment: 
On voit pourquoi ce mode de résultat était loin de remplir mes intentions; le mot prononcé, au lieu d'être le signe du besoin, n'était, relativement au temps oú il avait été articulé, qu'une vaine exclamation de joie. Si ce mot fût sorti de sa bouche avant la concession de la chose désirée, c'en était fait; le véritable usage de la parole était saisi par Victor; un point de communication s'établissait entre lui et moi et le progrès les plus rapides découlaient de ce premier succès. Au lieu de tout cela, je ne venais d'obtenir qu'une expression insignifiante pour lui et inutile pour nous, du plaisir qu'il ressentait. (Itard 1801: 397)

After the word lait Victor learned to pronounce two other monosyllables, $l a$ and $l i$, to which he later added a second $l$, being able to pronounce them as in the Italian word $g l i$; these were sounds that had no meaning for him, even though Itard supposed that these expressions could be related to the name Julie, the daughter of Ms. Guérin (Victor's nurse) who would come to visit her every Sunday. The language apprenticeship of Victor did not go much beyond these modest results, given that the only other words that he learned to pronounce were the two syllables Oh Dieu!, which were based on the imitation of a recurrent linguistic behavior of Ms. Guérin and which the boy used to express joy. However, the limited results achieved were not associated with any visible clinical pathologies.

The reasons for this failure lie in the fact that the theoretical premise used by Itard as a point of reference, namely Condillac's sensationalism, was fallacious. According to this premise, human nature, of which language is obviously an essential part, is genetically active in every individual at birth and can be awakened at any time. The case of Victor, on the other hand, confirmed the thesis that Monboddo (1714-1799) had expounded in his fundamental work On the Origin and Progress of Language (published in six volumes between 1773 and 1792) which included a first volume dedicated to the subject of the origin of language. Here Monboddo pointed out that the human natural powers are very limited and do not include faculties such as thought and language, which, therefore, are not inborn human abilities, but the fruit of habits acquired through education.

Only in more recent times, thanks to works such as Lev S. Vygotskij's (1896-1934) Thought and Language (1934) and Jean Piaget's (1896-1980) Psychologie de l'intelligence (1947), have scholars come to acknowledged that human nature is not a starting point, but the result of a complex process of development, which continues after birth throughout the long period of the child's development, through his communicative interaction with 
others: a process that, in Victor's case, was never accomplished. ${ }^{5}$ The harsh reality of Victor shows that no development of human nature is possible independently of culture, and especially of the acquisition of language. Without the guidance offered by an efficient semiotic system, no human mind is in condition not only to communicate, but also to organize experience and govern its behavior.

\section{Victor's cognitive re-education}

Itard's re-educational program aimed to achieve five goals: 1) making Victor interested in social life; 2) awakening his nervous sensibility; 3) widening his ideas; 4) teaching him how to speak by imitation; 5) stimulating his intellectual faculties, such as attention, memory, judgment, and all the sensory faculties, in order to apply them to subjects useful for Victor's education. As we have seen, while the results were not satisfactory with regard to the fourth goal, Victor made significant progress in relation to the points 1-3 and 5 of Itard's program. In the following part we will focus in particular on the results achieved in the development of mental faculties.

Even though learning to speak a language proved impossible for Victor, the child was able to communicate and interact with Itard and his housekeeper by means of a sign-language referred to as "pantomimic" in the physician's writings. As an alternative to speech, Itard tried to improve the child's ability to express himself through gestures and, at the same time, to understand similar signs when produced by other people:

C'est la facilité qu'a notre jeune sauvage d'exprimer autrement que par la parole le petit nombre de ses besoins (...). L'heure de la promenade est arrivée, il se présente à diverses reprises devant la croisée et devant la porte de sa chambre. S'il s'aperçoit que sa gouvernante n'est point prête, il dispose devant elle tous les objets nécessaires à sa toilette, et dans son impatience il va même jusqu'à l'aider à s'habiller. Cela fait, il descend le premier, et tire lui même le cordon de la porte. Arrivé à l'observatoire, son premier soin est de demander du lait, ce qu'il fait en présentant une écuelle de bois, qu'il n'oublie jamais, en sortant, de mettre dans sa poche, et dont il se munit pour la première fois, le lendemain d'un jour qu'il avait cassé, dans la même maison et pour le même usage, une tasse de porcelaine. (Itard 1801: 399)

5 For a more in-depth investigation of this topic, see Formigari (2007: 51-66). 
In Itard's writings we find other similar examples of the use of accidental signs, which are all note worthy and relate to different situations. In one of these examples, Victor, wishing to be carried on a cart during his walks in the countryside, takes someone's arm, leads him into the garden, puts the shafts of the cart in his hands and then immediately sits on it. Another example shows the way in which Victor expressed through actions the affections of his mind, such as boredom and impatience.

Other equally interesting examples are those related to the boy's ability to understand and recognize accidental signs: the nurse, Madame Guerin, shows Victor a pitcher instructing him to get some water; she turns it over and shows him that it is empty and Victor understands what she is asking him to do.

The reader will probably remember the film - L'enfant sauvage (1969) that François Truffaut based on Itard's two Mémoires and that features him as the protagonist in the role of the doctor and educator. It is not coincidence that the film places much emphasis on both the didactic exercises, and the effects that these have on Victor's needs and cognitive potential. In shooting of the film, Truffaut was intrigued by the human relationship that developed between teacher and pupil over time. He was probably also influenced by Arthur Penn's film, The Miracle Worker (1962), which tells the story of a governess who is able to teach Anna, a girl born blind and deaf, to overcome her handicap and to know the world through the exercising of touch. Arthur Penn's film is also based on a true story, that of Helen Keller, a girl who - like the protagonist - was not only blind, but also deaf: touch was the only means of communication available to her.

Initially, the script, which Truffaut wrote together with Jean Gruault, was divided into two parts of roughly the same length: the first concerned the capture of Victor in the forest and his first stay in the Institute for the Deaf and Dumb in Paris; the second regarded the work of re-education carried out by Itard with the assistance of Ms. Guerin. Afterwards, the director considerably cut the first part, which in the film only serves as the preface to the story, and focused all his attention on the process of re-education, carefully presenting the exercises and educational games created by Itard.

With the aim of streamlining the film, Truffaut turned Itard's scientific reports into a diary of a teacher, an account of his teaching that records successes, but also moments of reflection and disappointment. In the film, the latter are reported through a voice-over reading passages from Itard's diary, in order to highlight their epistemological value. Itard's narrative style - his écriture - also plays a role in L'enfant sauvage. In another of his films, Fahrenheit 451 (1966), Truffaut had already placed much emphasis 
on the power of writing. In this film being deprived of books is a symbol of slavery and subjugation from which the protagonist, Montag, begins to free himself when he steals a book, David Copperfield, and through writing, regains his lost subjectivity. The sequence in which Montag tries for the first time to read a book, learns to syllable with some difficulty, and tries to make up for the lost time, is one of the best in the film; this image of a man-child who, for the first time, looks at a written page mirrors that of the wild child who learns to use the signs of the alphabet, and thus begins to redeem his intelligence.

The series of educational exercises that Itard developed involved the identification of objects, designed to stimulate Victor's observational skills; they also aimed to extend his power of abstraction and to generate new needs. Representations of objects were gradually showed to the child, at first only in a graphical iconic form and then, at least in some cases, in a symbolic and abstract form. This was in tune with a concept of the development of the human mind, from concrete to abstract, which later, in the twentieth century, Piaget was to identify as the constituent phase of every learning process. This fundamental transition from concrete to abstract is evident in those exercises in which Itard, first, shows Victor drawings of some objects, such as keys, scissors, a hammer, etc.; then leads him to associate these objects with iconic representations and, finally, teaches the boy to associate the objects with the words representing them. In general, Victor performed the exercises with little effort. However, problems sometimes emerged. In an attempt to ensure that there would be an exact association between the drawings and the objects, regardless of their location, in subsequent repetitions of the exercises, Itard changed the position of the drawings. The result was that Victor continued to place the objects in the order in which they were presented for the first time, following his recovered mnemonic ability, but failing to establish correct correspondences between iconic signs and their referents. To overcome this problem, Itard increased the number of drawings when changing their positions, in order to make this new ability of the wild boy ineffective: only with this second expedient did Itard achieve a satisfactory result.

The final replacement of the drawings with the words designating their objects was designed to teach the use of institutional signs. In this case, however, Victor found it very difficult to identify objects corresponding to the alphabetic representations of their names, thus showing that the transition from objects to institutional signs was extremely problematic for him. It was therefore necessary for Itard to intensify the exercises and lead Victor to link each linguistic sign to its referent, in a more precise way, in order to establish some sort of identity between these two elements and simultaneously fix 
them in his memory. The results of these exercises were positive: one day Victor went to visit his neighbors along with his teacher and, wishing to ask for some milk, he arranged on the table the letters of the word lait ("milk"); previously, to express this request, he had always indicated the place where the food was stored, or shown the bowl used to drink. Therefore, Victor was finally able to express his needs using an institutional sign: in some specific cases the child went beyond the stage of langage d'action to which he was usually confined.

At this stage of the boy's re-education, Itard faced an additional difficulty: Victor was inclined to connect each linguistic sign with one and only one thing located in some place. For example, to his eyes, the word book always denoted a particular book, the concrete object of his experience and not a member of the class of objects indicated by this linguistic sign. In other words, Victor could not understand the symbolic function of the linguistic sign: for him every word was a "proper name" and not a general term denoting a multiplicity of referents. Victor found it very difficult to understand and master the process of abstraction, so well described by Locke in his Essay on Human Understanding $(1690)^{6}$ - the process which presides over the constitution of institutional signs and represents the precondition for inter-subjectivity.

What comes into play here is one of the central themes in the philosophy of language as well as semiotics, namely categorization, the process according to which object classes, denoted by names, appear to be constituted by individuals that are different in many ways, yet have some common properties allowing them to be subsumed under the same denotation. In order to foster this process Victor was led to observe the analogies between different objects, to identify common features and to collect the objects into separate categories; however, also in this case, Victor found it very difficult to build the classes of objects denoted by a name, confirming the fact that these processes are complex and require extensive constant training:

6 According to Locke, it is not by chance, but the result of reason and necessity that most of the lexicon consists of general terms. A language made up of proper names, each referring to a single person or referent, would go beyond the limits of human memory. Moreover, the generality of the name guarantees the intelligibility, by making it possible to refer to ideas that are, in some way common, to both the speaker and the listener. Without ideas and general terms we would not have any real language but only a series of idiolects. As all things in nature are particular, without language it would be possible to experience only this or that particular individual. On the contrary, there are many words in our lexicon designating classes of meanings, such as the word "man", which refers to an entire class of individuals, falling under the definition of the common man (Locke 1690: III/III, 6 and II/XI, 9). 
[S]ous le nom de livre, il désigna indistinctement une main de papier, un cahier, un journal, un registre, une brochure, ... tout morceau de bois étroit et long fut appelé bâton, ... tantôt il donnait le nom de brosse au balai et celui de balai à la brosse; et ... bientôt, si je n'avais réprimé cet abus de rapprochements, j'aurais vu Victor se borner à l'usage d'un petit nombre de signes, qu'il eût appliqués, sans distinction, à une foule d'objets tout à fait différent, et qui n'ont de commun entre eux que quelques unes des qualités ou propriétés générales des corps. (Itard 1807: 538)

There are other noteworthy educational exercises that Itard used in an attempt to make Victor understand the syntactic dimension of signs. For example in order to stimulate the boy's ability to reason, he would link a subject to various possible predicates and ask Victor to discern which links were correct, from a logical point of view, and which ones had to be discarded.

As can be seen from the examples quoted so far, the results of Victor's cognitive re-education are certainly noteworthy. In general, his progress, as Itard rightly pointed out, was really significant if compared to the condition of the child when he was found, and not to the communication skills of a teenager of the same age (the distance between them was still huge). At the end of his second Mémoire when referring to Victor's relationships with the people around him, Itard writes that Victor had become able to express his needs and conduct a free exchange of ideas. Optimistic as this conclusion may seem, Victor had proven able to engage in a genuine form of reasoning, more complex than that based only on the stimulus-response relation. Undoubtedly, Itard won the bet he had made on the possibility of reeducating Victor and in the light of the results attained, Pinel's objections were really quite baseless.

\section{Itard and the origins of modern pedagogy}

As a number of historical works have shown, ${ }^{7}$ the writings of Itard exerted a significant influence on the development of pedagogical reflection, also drawing on the important results achieved by Rousseau's Émile (1762) and Condorcet's Esquisse d'un tableau historique des progrès de l'esprit humain (1794). Based on these two fundamental works, the need to extend education

7 See the studies by De Bartolomeis (1953), Fornaca (1990) and Genovesi (2000). 
to all individuals had come to shape the French school system, which was designed to give everyone the opportunity to improve his/her skills and develop his/her natural abilities as far as possible. Over the centuries, as the experimental pedagogy gained increasing prominence, Itard's other writings - starting from the Traité des maladies de l'oreille et de l'audition (1821) and the Lettres au rédacteur du "Globe" sur les sourds-muets qui entendent et qui parlent (1826-1827) - became a reference point and an incentive for those involved in the re-education of the deaf and dumb.

IItard's writings, however, attracted the attention of many scholars from different disciplines. The point at issue was to establish systems of rehabilitation for individuals who had a developmental delay, and who, despite the severity of their conditions, gave - as in Victor's case at least some hope that they could be re-educated. A typical case in point is Maria Montessori (1870-1952), who, in her Manuale di pedagogia scientifica (1925), acknowledges her debt to Itard for the elaboration of didactic exercises which, through the activation of the child's sense-motor resources, stimulate the spontaneous development of the corresponding skills. Maria Montessori also shares with the French doctor the idea that the impulses to which the child is subjected must be selected in such a way as to systematically affect all the senses, gain his attention and awake his intelligence. The assumption here is that, at the beginnings of the therapy, very simple cognitive tasks must be performed in order to properly stimulate the mind, since starting from activities that involve high-level cognitive processes would be misleading. Montessori's handbook also endorses Itard's principle that any complex sensory acts which the impaired child is unable to perform must be broken down into simpler ones.

In the long run, Itard's teachings, along with those of Edouard Seguin (1812-1880) on idiocy and of John Langdon Down (1828-1896) on disability, gave rise to a new pedagogy, so-called "special" pedagogy, which sets itself the educational project of meeting the needs and capacities of the child with disabilities (Gelati 2000: 100-10). This kind of pedagogy is based, on the one hand, on sensationalist epistemology and, on the other, on a combination of medical, scientific and humanitarian skills. Its therapeutic approach considers the mentally impaired patient (e.g. the wild boy), not as a sick person, but as an individual with sensory and intellectuals deficits which, in some cases, may be reduced and in others, even completely overcome. In the twentieth century Maria Montessori herself became a leading representative of special pedagogy.

In conclusion, Itard's writings on the case of Victor, "the wild boy of Aveyron", are of epistemological as well as historiographical interest: 
on the one hand, they contributed to shedding light on issues that are central to the philosophy of language, such as the function language performs in the construction of human nature and the influence of social relationships on language development; on the other hand, they historically represent an important attempt to establish an effective system of communication for deaf-mutes, in the light of a pedagogical project for impaired children with cognitive delays.

\section{References}

Annacontini, G. (2002). Victor e Itard tra natura e cultura. Bari: Adda editore.

Barbera, A., Mosca, U. (1995). François Truffaut. Milano: Il Castoro.

Bertrand, A. (2002). (eds). Condillac. L'origine du langage. Paris: PUF.

Blanckaert, C. (1991) Premier des signes ou dernier des hommes, le métamorphoses de l'homme-singe au XVII-XVIII siècles. Alliage, 7-8.

Boyle, T.C. (2010). Wild child and other stories. New York: Viking Penguin.

Bresciani Califano, M. (eds). (2007). Infanzia e memoria. Firenze: Olschki.

Brogi, V., Mori, L. (eds) (2010). II bambino selvaggio. Pisa: Edizioni Ets.

Chappey, J.L. (2002). La société des observateurs de l'homme (1799-1804).

Des anthropologues au temps de Bonaparte. Paris: Société des études robespierristes.

Chiricò, D. (2014). Diamo un segno. Per una storia della sordità. Roma: Carocci.

De Bartolomeis, F. (1953). Maria Montessori e la pedagogia scientifica. Firenze: La Nuova Italia.

Formigari, L. (1981). La scimmia e le stelle. Roma: Editori Riuniti.

Formigari, L. (2001). Il linguaggio. Storia delle teorie. Roma-Bari: Laterza.

Formigari, L. (2007). Introduzione alla filosofia delle lingue. Roma-Bari: Laterza.

Fornaca, R. (1990). Storia della pedagogia. Firenze: La Nuova Italia.

Gazzeri, C. (2015). Sordità e lingue segnate: pratiche educative e riflessioni teoriche nella Parigi illuminista. In Marras and Schino (eds.) (2015): 101-12.

Genovesi, G. (2000) (eds). Rileggendo Itard. Bologna: Pitagora editrice

Gineste, T. (2004). Victor de l'Aveyron. Dernier enfant sauvage premier enfant fou. Paris: Hachette.

Hervé, G. (1911). Le sauvage de l'Aveyron devant les observateurs de l'homme avec le rapport retrouvé de Pinel. Revue anthropologique 10-11.

Itard, J. (1801). Mémoires sur les premiers développements de Victor de l'Aveyron. In Gineste (2004): 361-486.

Itard, J. (1807): Rapport sur le nouveaux développements de Victor de l'Aveyron. In Gineste (2004): 512-66.

Lane, H. (1976). The wild boy of Aveyron. Cambridge: Harvard University Press.

Locke, J. (1690). Essay on human understanding. Oxford: Clarendon Press 1975. 
Ludovico, A. (2006). Anima e corpo. I ragazzi selvaggi alle origini della conoscenza. Roma: Aracne.

Malson, L. (1964). Les enfants sauvages. Paris: Hachette.

Manetti, G. (2007). L'infanzia di Tarzan e la memoria dei ragazzi selvaggi. In Bresciani Califano (2007): 111-134.

Manetti, G. (2010). Victor ragazzo selvaggio e la pedagogia linguistico-cognitiva di Jean Marc Gaspard Itard. In Brogi V. and Mori L. (2010): 35-64.

Mannoni, O. (1965). Itard et son sauvage. Les temps modernes XXI: 647-663.

Marras, C., Schino, L. (eds) (2015). Linguaggio, filosofia, fisiologia nell'età moderna. Roma: Iliesi CNR. (Avalaible online: http://www.iliesi.cnr.it/pubblicazioni/ Ricerche-01-Marras_Schino.pdf)

Moravia, S. (1970). La scienza dell'uomo nel Settecento. Bari: Laterza.

Moravia, S. (1972). Il ragazzo selvaggio dell'Aveyron. Bari: Laterza.

Pandolfi, A. (2006). Natura umana. Bologna: Il Mulino.

Pennisi, A. (1992). Le lingue mutole. Roma: NIS.

Prato, A. (2012). Filosofia e linguaggio e nell'età dei lumi. Da Locke agli idéologues. Bologna: I libri di Emil.

Quarfood, C. (2002). Condillac, la statue et l'enfant. Philosophie et pédagogie au siècle des Lumières. Paris: L'Harmattan.

Ricken, U. (1982). Linguistique et anthropologie chez Condillac. In Sgard (1982): 75-94.

Robins, R.H. (1982). Condillac et l'origine du langage. In Sgard (1982): 95-102.

Sacks, O. (1991). Seeing voices. A journey into the world of the deaf. New York: Summit Books.

Sgard, J. (1982). (eds). Condillac et les problèmes du langage. Genève-Paris: Slatkine.

Shattuck, R. (1980). The forbbiden experiment. The story of the wild boy of Aveyron. New York: Farrar Straus Giroux.

Takesada, T. (1982). Imagination et langage dans l'Essai sur l'origine des connaissances humaines de Condillac. In Sgard (1982): 47-58.

Tinland, F. (2003). L'homme sauvage. Homo ferus et homo silvestrus de l'animal à l'homme. Paris: L'Harmattan. 